\title{
Trinucleotide Repeat-Containing Gene 6B Protein
}

National Cancer Institute

\section{Source}

National Cancer Institute. Trinucleotide Repeat-Containing Gene 6B Protein. NCI

Thesaurus. Code C134310.

Trinucleotide repeat-containing gene 6B protein (1833 aa, $\sim 194 \mathrm{kDa}$ ) is encoded by the human TNRC6B gene. This protein plays a role in RNA-mediated repression of translation. 